\title{
Singapore Cinema: Director Eric Khoo Speaks Up
}

\author{
By Jan Uhde and Yvonne Ng
}

Fall 1999 Issue of KINEMA

ERIC KHOO was born in 1965 to a well-to-do family in Singapore. According to Khoo, his mother started taking him to the movies at the age of two, developing in him a love for the cinema (delete sentence- repeated in main text). According to Khoo, when he was about eight years old, he (chanced upon) his mother's Super 8 camera, started making "little animated films" on it and has since been unable to put his camera down. Khoo's interest led him to study cinematography at the City Art Institute in Sydney, Australia. Back in Singapore, he began making award-winning short films before venturing into feature film-making.

In 1990, Khoo's animated short film, Barbie Digs Joe, won five awards at the Singapore Video Competition and became the first Singapore short film to travel to film festivals abroad. His next short, August (1991) won the Best Singapore Short Film at the $4^{\text {th }}$ Singapore International Film Festival. This was followed by the short films Carcass (1992) and Symphony 92.4 (1993). However, the short that brought Khoo notoriety at home and abroad was Pain (1994), a graphic portrait of a sado-masochistic young man's obsession with pain, described by a critic from the Belgian paper Le Soir as "an artistically and truly disturbing movie in its honesty." The film won Khoo the Best Director and Special Achievement Awards at the 1994 Singapore International Film Festival but was banned from public exhibition for its portrayal of a person who commits a hideous crime of brutality and torture. The ban on Pain remained until 1998 when it was screened at the $11^{\text {th }}$ Singapore International Film Festival. Khoo has also produced numerous music videos and television commercials. In February 1999, Khoo was named in Asiaweek magazine as one of 25 exceptional Asians for his influence on film and television. In June of the same year, he received the Singapore Youth Award in recognition of his contribution to the country's film industry. Khoo's professional reputation rests mainly on his two features, the psychological drama Mee Pok Man (1995) and the realistic portrait of urban alienation in 12 Storeys (1997), which earned their author praise at home and abroad.

In March 1999, Jan Uhde and Yvonne Ng asked Eric Khoo for his perspective on filmmaking in Singapore and to comment on the island's remarkable revival of feature production. The interview is an extract from their book on film in Singapore which will be published in the Spring of 2000.

\section{Q.: What type of films do you like to make?}

A.: Like everything I've done in the past, the basic story is about human life. I like little dramas rather than action film or big-budget film. What I am doing at this point are simple little stories, hopefully stories that can live on. As a little boy, my main influence were Spaghetti-Westerns, James Bond, Bruce Lee. My mother brought me to the cinema when I was about two years old; and I grew up on a diet of fantasy films. That was essentially my childhood. I also read a lot of comic stories like Spiderman. When I hit 11 or 12 , I saw this movie called Taxi Driver by Scorsese and I said, there's more to cinema than just monsters or dinosaurs. Ever since then I was always very much for the anti-hero, the guy that gets screwed-up. So far in the works I have done, from my shorts to my two features, I am attracted to characters that don't function too well and have to exist within society's rules and regulations.

\section{What do you need to make the film you want?}

Making a film here is expensive. Even if you're doing a small tight-budget film, it would cost at least halfa-million dollars now. So when I was doing 12 storeys the budget was $\$ 300,000$ and we managed to cap it at $\$ 280,000$. We managed to do that because when we were working on the script we realised we did not want too many locations. The shots had to be quite simple and yet have a narrative that would capture an audience for an hour and a half. We managed to finish it in two weeks from the conception of the idea to the end result with this amount of money. Even when we did Liang Po Po with Raintree Pictures, the main thing was to keep the budget at $\$ 800,000$. So it depends on the budget and how you are going to tell the story within that budget.

When we created the concept for 12 Storeys, I very much wanted this film to have a PG rating, so that it would reach up to all the satellite towns. You may call it self-censorship in the sense that I did not want to get an R(A) rating as did Mee Pok Man. An R(A) picture would not see any video release unless you allow 
them to cut it. In the case of Mee Pok Man I did not want them to cut it because if you cut it you'll have a silent film. An R(A) also means you'll have a limited audience. On the other hand the Mee Pok Man was done for under $\$ 100,000$ and so it paid off at the box-office.

You mentioned Taxi Driver. Could you say something about which other films or film-makers have had an influence on you? What I liked very much in Taxi Driver was the central character played by Robert De Niro. I remember I had the soundtrack album and would repeat it every night. I like its visual style, its execution and the story about how this crazy guy tried to save a prostitute also touched me. Later on, I managed to watch the Midnight Cowboy when I went to Australia to study. In Australia, I had the privilege of watching a lot of films that were either banned or totally butchered in Singapore. Basically I just hung out at a video store, borrowed as much as I could and watched a lot of films. So my film education in Australia was not so much going to film school, it was more being able to watch a wide range of films.

I like the films of Aki Kaurismäki, the Finnish director, I think he is a gem. And Krzysztof Kieslowski's, Dekalog, I think that's one of the best films ever done for TV, although almost nobody has seen it here. I also like the works of Shinya Tsukamoto, the Japanese director, Steven Spielberg and Robert De Niro.

\section{You have made both shorts and features. Do you prefer one over the other?}

Both mediums are very exciting. And the short film is great because essentially you have to tell a story within thirty minutes. That means you've got to get the viewer engrossed in the first five minutes. Also, in all my little shorts I worked with this guy who owns a post-production house and said "look, if I win a prize, we'll share the money." So I did not have to worry too much about budgets. So I could be very self-indulgent. My short films were almost like homework, a learning process which eventually gave me the courage to do a feature-length film. I experimented with films that were just like silent film, from the point of view of a dog, and it was great. In that area it was very easy to be as creative as you could. You did not have to worry about investors, or how many halls it's going to be screened in. If I were to do a short film now I'd do it just for myself. What I have been doing ever since my first child was born, has been to film him every day. Eventually when he reaches 21 years old, I'll show him five minutes worth of videotape in which he'll see himself grow up.

We were also commissioned by TCS to do Drive, a six part-series. I wanted it to be like an anthology in which I would get different writers, directors, directors of photography, and also with the students of Ngee Ann. My main concern was how to keep the viewer off the video-channel surf for the 45 minutes of each episode. A lot of those who came on board for this project, were definitely influenced more by art-house cinema than mainstream cinema. They were able to at least come up with material which I thought was essential for TV viewing. At the end we rated about six to seven per cent which wasn't too bad. So in the end you need to know who your target audience is, what you want to say and how you are going to say it.

I also wanted this project to be a platform for young aspiring filmmakers. I was the executive producer of all six episodes but I also directed one of them. The other directors were all new with the exception of Sandi Tan who had won a prize for her short film at the Singapore Film Festival a few years back. After we put out the word for scripts to come in, a lot of people came forward and what we did was to send all the scripts to TCS to see which ones they wanted. I was very happy because the ones that were approved were also the ones I wanted to do, with the exception of one or two which they felt were too sensitive.

\section{Do you think that auteur films have a chance here?}

Yes, but in the end films made here will have to travel because it is too small a market. If you look at Hong Kong, with a population of six million, they could never have the industry they have if it was not for the support of Asia. If a film is good enough and marketed well it can probably make some money. For example Shall We Dance made some US $\$ 10$ million in the US and it is a Japanese film. Life Is Beautiful cost $\$ 9$ million and brought back US\$140 million internationally. And The Sweet Hereafter cost US\$3 million and returned US $\$ 10$ million. On the other hand if you look at Titanic, it made a billion dollars but in relative terms it didn't really make that much.

What you think about government support in film education?

It's getting better with the Singapore Film Commission and with the new film programmes at Ngee Ann and Temasek Polytechnics. New graduates are coming out and working in the industry so that's a plus point. A 
lot of these young students are very enthusiastic and I think that's what's needed.. Because if you look at the old hands, basically 40-year old guys, they were only trained to do TV series - for them it's just work. So I think with this new enthusiastic lot being injected into the industry, it will help.

\section{What are you working on now?}

On a script. As for [Khoo's film production company] Zhao Wei, there are two things. We would like to produce films with other directors and I would also like to direct again. But I must be comfortable with the script. Normally, the scripts I like have some sort of skeleton that I am familiar with. For instance, I would never have attempted to direct Liang Po Po although I enjoyed the script when I read it. Right now there are two projects being developed. I'd like to get other people to direct one and the other I'll probably tackle myself.

\section{Do you write your own scripts?}

I come up with certain ideas but then I'll have to collaborate with somebody else, because I hate writing dialogue. I hate giving the skeletons the meat and the organs.

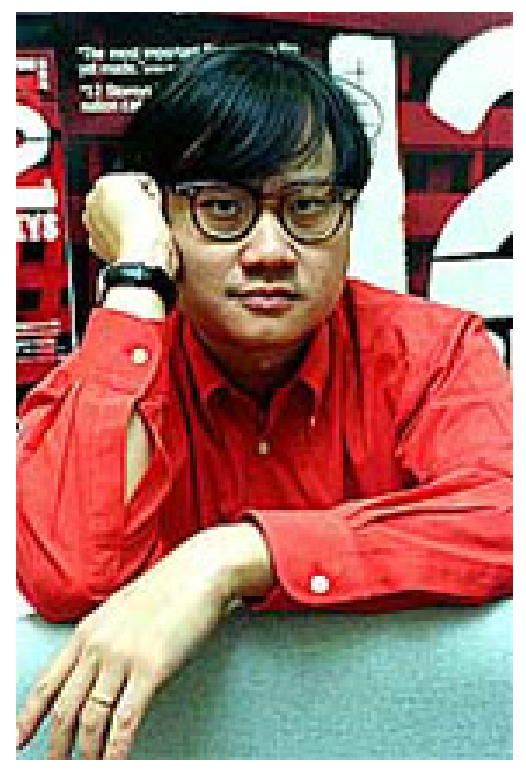

Figure 1: Director Eric Khoo

What do you think is behind the recent Singapore film revival? I'd say there are two areas to this. We did Me Pok Man in 1995 and that got Singapore film some attention but I think what really woke people up was Money No Enough which was a big box-office hit. Suddenly you have an array of investors saying, "Hey I've got money, let's go, let's go!" They don't want to speculate on the stock-market because they are scared of Asia's economy but they will invest in film and entertainment, especially with the Singapore Film Commission and Singapore Tourism Board's support. The problem is that they could be having a false sense of security. If the next couple of films that come out are duds, all the investors will run away and we could be back to where we started twenty years ago. Right now I think there is a lot of hype about Singapore film.

\section{What should be done to increase the chances of success of Singapore's film industry?}

I think the most important thing is the script. You need a good script, you need a director who feels a lot for the script, a whole team who feels a lot for the script. Making a film is not a one-person thing; it's the cast, the crew, the whole package. When I draw comics I can do it by myself. Whether they work or not, I can take the full burden upon myself but when you are making a film it's different.

\section{How do you feel about the level of acting here?}

We've got a young population that is quite strong and confident in front of the camera. A lot of young kids are coming for audition. When you look at them you say, man, they are pretty feisty. When I was at their age I don't think I was as courageous. There are basically two schools of acting here - theatre and television. 
And that's because there was no film industry for a long time here. I've had no problems so far getting amateurs. I think sometimes when you create a story, it is easier to get someone who is similar to the story's character and then say to him, just be yourself. If the dialogue is interesting then it will be interesting also for an actor to interpret what he or she has to say.

What would you recommend to aspiring film-makers in Singapore?

You could have a good story taking place in one room. Some of the ideas in scripts I read are so big and complicated you know they can never be realised. Some of the big-budget commercial films are actually weak on script but strong in terms of visuals. In Singapore, we could definitely do a tight story like Jim Jarmusch's Stranger Than Paradise which is really good. For such films there'll always be an audience whether it is an independently produced film or not.

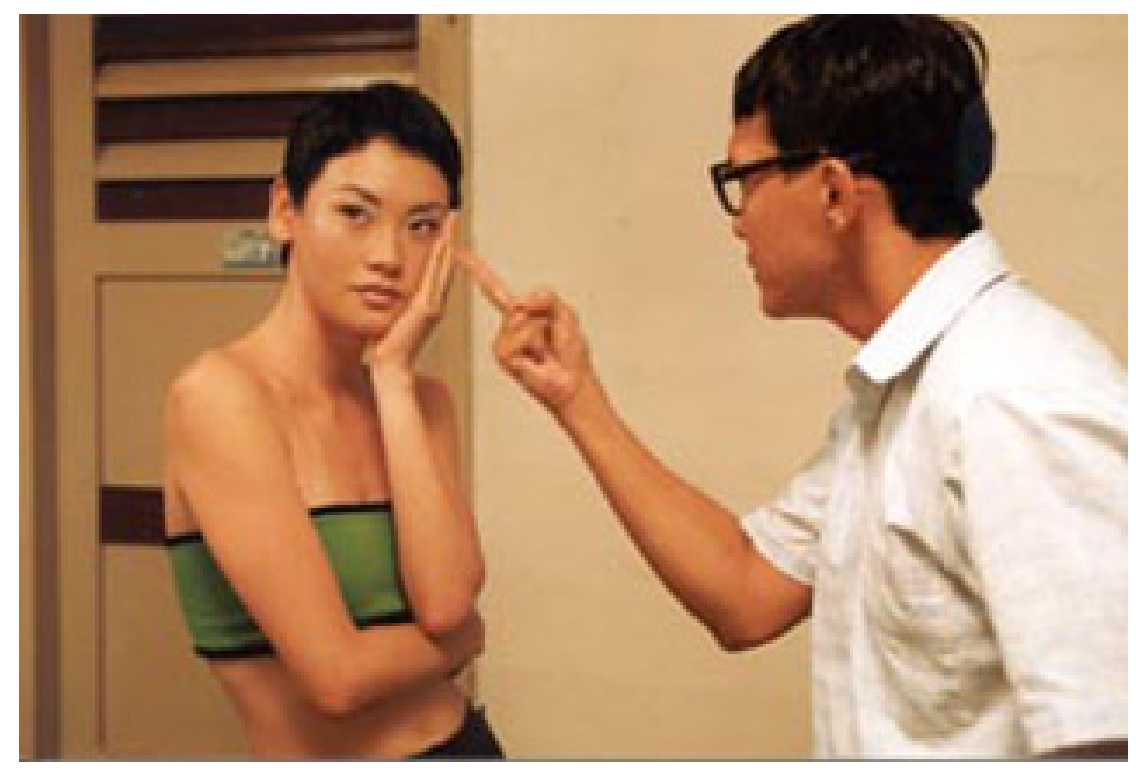

Figure 2: 12 Storeys (Lum May Yee and Koh Boon Pin) 